\title{
Fire Effects on Nitrogen Mineralization and Fixation in Mountain Shrub and Grassland Communities
}

\author{
N. THOMPSON HOBBS AND DAVID S. SCHIMEL
}

\section{Abstract}

Prescribed burns were carried out in mountain shrub and grassland communities in the montane zone of the Rocky Mountains in Colorado. Nitrogen mineralization rate was increased 1 year after the burn in both communities. This increase persisted for 1 year in the grassland and for 2 years in the shrub community. Total mineralized soil- $N$ was greater in the burned than unburned areas of both communities during the first growing season after fire. An acetylene reduction assay for nitrogenase activity showed depressed activity 1 year after the burn. We suggest that elevated inorganic $N$ levels caused the reduction in nitrogenase activity.

The influence of fire on the nitrogen economy of ecosystems has been widely studied. Fire acts as a potent mineralizing agent, causing the rapid transformation of organic nitrogen to inorganic forms (Christensen 1973, St. John and Rundel 1976, Dunn et al. 1979). Fire results in alterations of the abiotic environment, which in turn lead to changes in biotic processes (reviewed by Viro 1974, Raison 1979). Elevated soil temperatures that result when the plant canopy is removed and the release of cations in ash improve conditions for microbial growth in the soil environment (Christensen and Muller 1975, Tiwari and Bharat 1977, Raison and McGarity 1980). It follows that nitrogen transformations mediated by microbial populations should be similarly altered by burning.

Despite the scrutiny that ecosystem effects of fire have received, few studies have examined the influence of fire on biotic transformations of nitrogen. Dunn et al. (1979) reported that nitrogen mineralization was stimulated following fire, but Schimel (1982) found that repeated burning reduced potentially mineralizable $\mathrm{N}$. Although Jorgensen and Wells (1971), Youngberg and Wollum (1976), and Grove et al. (1980) observed that fire increased rates of nitrogen fixation in forest ecosystems, no work to date has examined these effects in mountain grassland or shrub communities. Prescribed burning is widely used in these communities to improve range conditions for wild and domestic animais; however, the ecosystem effects of such application are poorly understood. Here, we report experiments on the influence of fire on nitrogen mineralization, nitrogenase activity, and soil inorganic $\mathrm{N}$ in mountain shrub and grassland communities during 2 years following burning.

\section{Materials and Methods}

We conducted our studies in a south-facing mountain valley at 2,500 m in elevation $2 \mathrm{~km} \mathrm{NE}$ of the town of Rustic, Colo. Vegetation on the study area is typical of the upper-montane climax region (Marr 1967); dry meadows, dominated by Agropyron spicatum (bluebunch wheatgrass) and Stipa comata (necdle and thread),

Authors are wildlife researcher, Colorado Division of Wildlife, $317 \mathrm{~W}$. Prospect, Fort Collins, Colo. 80526; and research ecologist, Natural Resource Ecology Laboratory, Colorado State University, Fort Collins 80523.

This research was supported by Federal Aid to Wildlife Restoration Project W-144$\mathbf{R}$. The authors gratefully acknowledge the laboratory assistance of L. Stevens, $\mathbf{J}$. Ritchie, and $\mathrm{C}$. Weinland. Analysis for $\mathbf{N}$ mineralization was conducted by $\mathbf{R}$. Woodmansee; nitrogenase activity was assayed by $D$. Klein. The authors also wish to thank N. McEwen for manuscript preparation and D. Bowden for statistical analysis. W. Hunt, D. Swift, D. Baker, and an anonymous referee gave helpful comments on carly drafts.

Manuscript accepted November 7, 1983 spread across the valley floor and merge with dense stands of shrubs, predominantly Artemisia tridentata (big sagebrush) and Purshia tridentata (antelope bitterbrush), on steeper slopes. Soils are composed of decomposed granite and mica-schists and are classified as Dystric Eutrochrepts. Organic matter content of soils in the surface $5 \mathrm{~cm}$ averaged $8 \%$ in mountain shrub and $11 \%$ in grassland and was unaffected by burn treatments.

We chose 3 pairs of plots in each plant community, the members of each pair being similar in slope, aspect, vegetative cover, and soil moisture. Plots were 0.3 ha in size in grassland and 1.0 ha in mountain shrub. Treatment was randomly assigned to 1 member of each pair of plots.

Treatment plots were burned on September 29 and 30, 1979. Treatment was not uniform across all plots because of differences among plots in fuel loadings, time of ignition, and thus fire intensity. Energy release by fire measured by water can analogs (Beaufait 1966) was substantially greater in mountain shrub $(\bar{x}=32 \mathrm{kcal}$, $\mathrm{SE}=8 \mathrm{kcal})$ than in grassland ( $\bar{x}=8 \mathrm{kcal}, \mathrm{SE}=0.3 \mathrm{kcal})$. Plots in mountain shrub burned more completely and intensely than plots in grassland. Pretreatment fuel loads and detailed fire behavior measurements have been described previously (Hobbs and Spowart 1984).

During the following 2 growing seasons, we estimated soil concentrations of $\mathrm{NO}_{2}{ }^{-}+\mathrm{NO}_{3}{ }^{-}$and $\mathrm{NH}_{4}{ }^{+}$and the rates of nitrogen mineralization and fixation (nitrogenase activity) on burned and unburned plots. Mineralization was estimated by the buried bag technique of Eno (1969). On June 4, 1980 and 1981, 20 soil cores (5 $\mathrm{cm} \times 5 \mathrm{~cm}$ ) were taken at random locations on each plot. Each core was split longitudinally and sieved through a $2-\mathrm{mm}$ mesh screen to remove large roots and rocks. Half of each core was placed in a polyethylene bag and replaced in the ground at depth similar to the original core and covered with $1 \mathrm{~cm}$ litter and/or surface soil. The remaining portion was immediately taken to the laboratory for analysis.

Within 10 hours of taking samples, we extracted a 3-g subsample of each core with $2 \mathrm{M} \mathrm{KCl}$ containing $5 \mathrm{ppm}$ phenyl-mecuric acetate added to inhibit microbial activity. Moisture content of a separate 5-g subsample was determined gravimetrically; organic matter was determined by loss on ignition. Ammonium content was determined by a colorimetric ammonium reaction with salicylate nitroprusside at $\mathrm{pH} 13 ; \mathrm{NO}_{3}{ }^{-}+\mathrm{NO}_{2}{ }^{-}$was determined by a cadmium reduction using a continuously copperized reduction column. Six weeks later, we retrieved the buried polyethylene bags and treated those samples the same as described for the initial samples. Net mineralization was estimated as the increment in total inorganic nitrogen $\left(\mathrm{NH}_{4}{ }^{+}, \mathrm{NO}_{2}{ }^{-},+\mathrm{NO}_{3}\right)$ between 2 sample dates.

Potential heterotropic nitrogenase activity was estimated with the acetylene reduction procedure as described by Hersman and Klein (1979). Thirty 5-cm soil cores were taken from random locations on each plot on June 10,1980, and June 12, 1981, and analyzed within 2 days of sampling. For each plot, cores were composited into 3 samples of 10 cores each, placed in plastic bags, and immediately cooled to approximately $5^{\circ} \mathrm{C}$ in a portable ice 
chest. Upon returning it to the laboratory, each composite was sieved through a $2-\mathrm{mm}$ screen and mixed. Twenty subsamples were selected from different locations within each composite and were mixed to form a 10-g sample for analysis; these samples were stored in plastic bags at $10^{\circ} \mathrm{C}$. Immediately prior to analysis, samples were wetted to field capacity with distilled water. We expressed nitrogenase activity as p moles ethylene produced.

Responses were analyzed with an analysis of variance for a split plot design with plant community type forming the whole plot, and burn vs. control contributing the split plot. Differences among individual means were established with Tukey's $Q$ simultaneous comparisons at $\boldsymbol{P}=\mathbf{0 . 1 0}$. Years and replicates were considered random effects.

\section{Results and Discussion}

We observed that fire resulted in significant $(P<0.10)$ increases in $\mathrm{NH}_{4}{ }^{+}$and $\mathrm{NO}_{2}^{-}+\mathrm{NO}_{3}^{-}$contents of grassland and mountain shrub soils 10 months after the burn (Fig. 1). This effect, however,

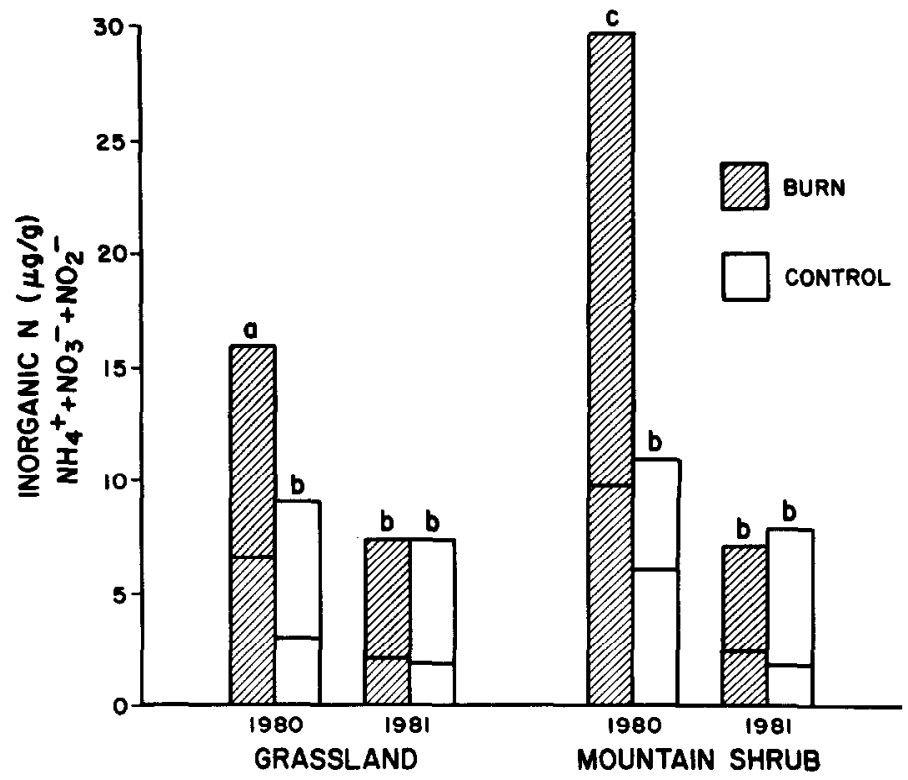

Fig. 1. Soil concentrations of inorganic nitrogen $\left(\mathrm{NH}_{4}{ }^{+}+\mathrm{NO}_{3}{ }^{-}+\mathrm{NO}_{2}{ }^{-}\right)$in mountain shrub and grassland communities on June 4, one and two years after prescribed burning. Different letters indicate differences in means at $\mathbf{P}=0.10$. Upper portion of bars shows contribution of $\mathrm{NH}_{4}$, lower portion shows $\mathrm{NO}_{3}^{-}+\mathrm{NO}_{2}^{-}$.

disappeared in the second year (year $\times$ treatment interaction $P=$ 0.05 ); soil mineral $\mathrm{N}$ values were significantly higher on burns during Year 1, but returned to control levels during Year 2. We attribute this return to uptake of $\mathbf{N}$ by the recovery plant community; above-ground plant biomass on burned plots was almost 3 times greater during Year 2 compared with Year 1 (Hobbs unpublished data). Reduced levels of inorganic $\mathrm{N}$ may also have been due to increased microbial uptake, denitrification, or leaching. Surface soils were probably temporarily sterilized. The winter following the burn was exceptionally severe; microbial populations had little opportunity to recover prior to the first sample.

Effects of fire on soil mineral $\mathrm{N}$ also depended on plant community (community $\times$ treatment interaction $P=0.12$ ). The larger increases in $\mathrm{NH}_{4}{ }^{+}$in mountain shrub relative to grassland likely resulted from the more even nature of the burn. The patchy distribution of burned areas within grasslands resulted in some treatment plots being similar to controls while in the mountain shrub practically all the area was burned.

Net mineralization of soil $\mathrm{N}$ was significantly greater $(P=0.10)$ on burned grassland plots during Year 1 , and on burned mountain shrub plots during both years (Fig. 2). Dunn et al. (1979) and Sharrow and Wright (1977) also found that rates of nitrogen

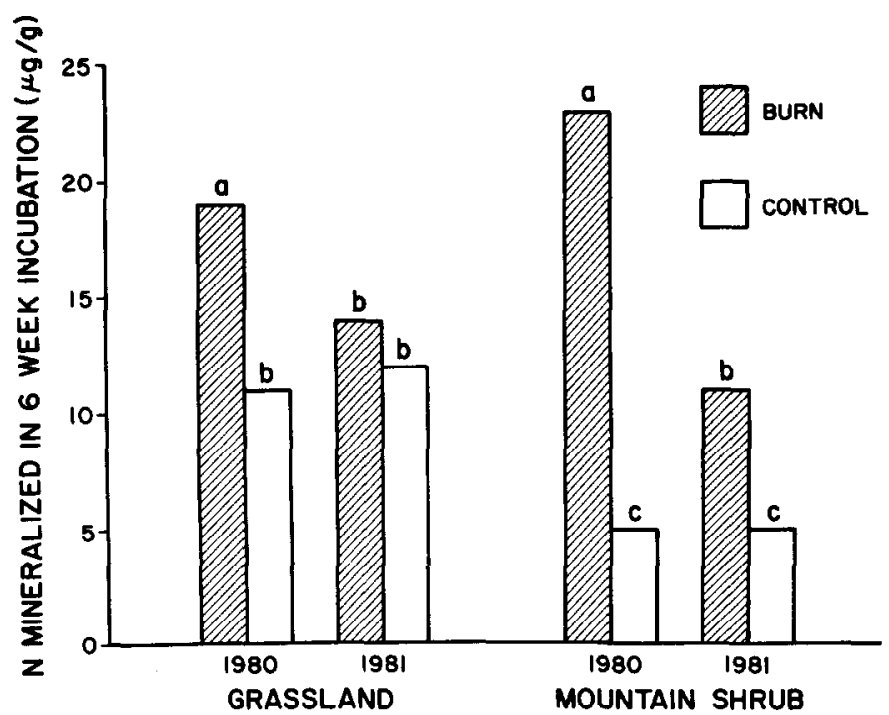

Fig. 2. Net mineralization rate in mountain shrub and grassland communities during the 6-week growing season, one and two years after treatment. Different letters indicate differences in mean values at $\mathrm{P}=0.10$.

mineralization were increased by burning. However, although a single fire may increase amount of $\mathrm{N}$ mineralized, the cumulative result of several fires inhibit it. Schimel (1982) and Biederbeck et al. (1980) suggested frequent fires led to decreased mineralization as a result of reductions in pools of readily decomposable $\mathrm{C}$ and $\mathrm{N}$ and resultant decreases in microbial biomass.

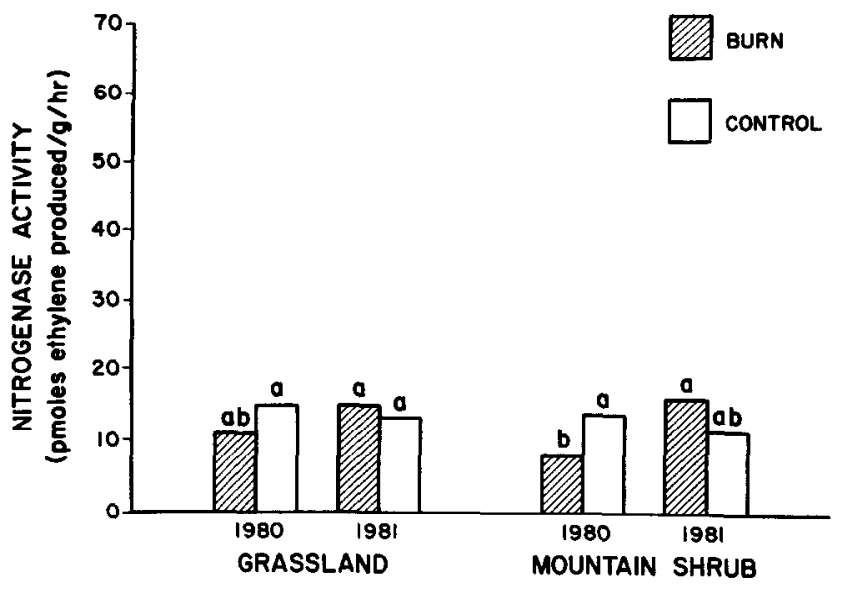

Fig. 3. Nitrogenase activity (acetylene reduction) in mountain shrub and grassland communities, one and two years after treatment. Different letters indicate differences in means at $\mathrm{P}=0.10$.

The magnitude of fire effects on net mineralization depended on year (year $\times$ treatment interaction $P=0.11$ ) and vegetation type (community $\times$ treatment interaction $P=0.005$ ); treatment effects were greater in mountain shrub than grassland, and declined in magnitude during Year 2. Main effects and interactions can be explained by changes in the soil environment. Soils in burned grasslands are typically $3-16^{\circ} \mathrm{C}$ warmer than similar unburned sites (Weaver and Rowland 1952, Kucera and Ehrenreich 1962, Scotter 1963, Old 1969, Lloyd 1972, Peet et al. 1975). This increase results primarily from absorption of solar radiation on blackened 
soils unshaded by litter and plants (Woodmansee and Wallach 1981). Nitrogen mineralization rate increases with increasing temperature (Stanford et al. 1973, Campbell et al. 1981). The effect of increased soil temperatures on $\mathrm{N}$ mineralization may have resulted in the elevated mineralization rates we observed. Immobilization of $\mathrm{N}$ into remaining litter may also have been a factor. Both of these explanations are consistent with the temporal and spatial interactions in treatment effects. Plant biomass on the burned plots of grassland was equal to the control by June of the second year; the difference in soil temperatures and the consequent divergence in $\mathbf{N}$ mineralization disappeared by Year 2 in that community. In contrast, total aboveground biomass in the mountain shrub community had not recovered to control levels by Year 2 and large areas of bare soil remained. As a result, we surmise that elevated soil temperatures would have persisted into Year 2. A similar pattern existed with respect to the immobilization potential of remaining litter. The mountain shrub community was burned intensely enough to remove all litter, while in the grassland some litter remained. Thus, the prolongation of increased $\mathrm{N}$ mineralization in the mountain shrub community is attributable to the greater intensity of the burn which occurred there, the slower recovery of the plant canopy, and the complete removal of the litter layer. The effect of fire on $\mathrm{N}$ mineralization in grassland was more brief because the fire was more heterogeneous and less intense. As a result, the recovery of plant canopy was more rapid and some litter remained.

Potential nitrogenase activity was lower on burned plots than controls during Year 1; however, this effect was significant only in mountain shrub $(P=0.10)$ (Fig. 4). Magnitude of treatment effects

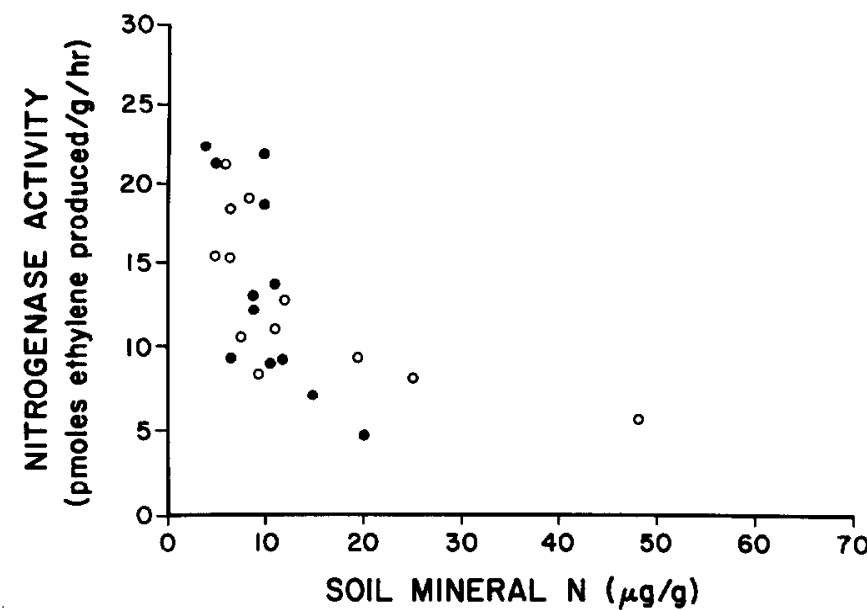

Fig. 4. Relationship between potential nitrogenase activity (acetylene reduction) and soil mineral $N$ in mountain shrub (open circles) and grassland communities (closed circles). Equation is given by $Y=39.6 X^{.53}, \mathrm{P}=0.0004, R^{2}=0.42$.

depended on year (year $\times$ treatment interaction $P=0.07$ ) but not on plant community (community $\times$ treatment interaction $P=$ $0.74)$. The reduction in nitrogenase activity may have resulted from sterilizing effects of fire. However, the inhibition of nitrogenase activity on burned plots during Year 1 and the return to control levels the following year appeared to be related to the concentration of mineral $\mathrm{N}$ in soils. Mineral $\mathrm{N}\left(\mathrm{NH}_{4}{ }^{+}, \mathrm{NO}_{3}{ }^{-}+\mathrm{NO}_{2}\right)$ was increased in soils of burned plots during Year 1 but not in Year 2. The reduction in potential nitrogenase activity was greatest in the mountain shrub community and the increase in soil inorganic $\mathrm{N}$ was also greatest there. Soil mineral $\mathrm{N}$ levels accounted for $42 \%$ of the variation in potential nitrogenase activity (Fig. 4); free-living and symbiotic nitrogen fixers decrease fixation when mineral $\mathrm{N}$ is elevated (Oghoghorie and Pate 1971, Manhart and Wong 1979, Wong 1980).

Our observation of a curvilinear relationship between nitrogenase activity and soil mineral $\mathrm{N}$ suggests that fixation responds in a threshold manner with respect to mineral $\mathrm{N}$ and that nitrogenase activity is reduced drastically at soil mineral $\mathrm{N}$ concentrations $>10-20 \mu \mathrm{g} / \mathrm{g}$ dry soil. These findings are at odds with reports that fire increases rates of nitrogen fixation (Jorgensen and Wells 1971, Youngberg and Wollum 1976, Grove et al. 1980). However, we cannot exclude the possibility that $\mathrm{N}$ fixation may become significant after $\mathbf{2}$ or more years, that inorganic $\mathbf{N}$ would not have been elevated had the burn been followed by a more normal winter, or that previous studies involved soils with lower levels of mineral N. A better understanding of the controls of $\mathrm{N}$-fixing organisms is required to better predict post-fire responses.

\section{Conclusions}

Fire caused increased rates of $\mathrm{N}$ mineralization for 1 year in a mountain grassland, and for 2 years in a mountain shrub community. The rapid recovery of the vegetation in the grassland caused rapid convergence of burned to unburned conditions. The shrub community burned more evenly and more severely, and so required longer to return to control conditions. We attribute most of the increase in $\mathrm{N}$ mineralization to increased soil temperatures.

Nitrogenase activity was depressed by fire 1 year after the burn in the mountain shrub community. This may have resulted from partial sterilization of the soil. In addition, soil inorganic $\mathrm{N}$ levels were elevated in burn relative to control plots and this probably contributed to the depression in nitrogenase activity.

The effect of fire was to increase the rate of $\mathbf{N}$ mineralization, and presumably, the availability of $\mathrm{N}$ to vegetation. Nitrogen losses doubtlessly occurred from the burned vegetation, and these may not have been rapidly compensated for by $\mathrm{N}$-fixation. Consequently, we recommend that prescribed burns for range improvement in montane communities not be repeated frequently on the same sites until fire effects on $\mathrm{N}$ budgets in these communities are better understood.

\section{Literature Cited}

Beaufait, W.R. 1966. An integrating device for evaluating prescribed fires. Forest. Sci. 12:27-29.

Biederbeck, V.O., C.A. Campbell, K.E. Bowrer, M. Schnitzer, and R.N. McIver. 1980. Effect of burning cereal straw on soil properties and grain yields in Saskatchewan. Soil Sci. Soc. Amer. J. 44:103-111.

Campbell, C.A., R.J.K. Myers, and K.L. Weier. 1981. Nitrogen mineralization potentials, decomposition rates, and their relationship to temperature for fire in Queensland soils. Aust. J. Soil Res. 19:111-124.

Christensen, N.L. 1973. Fire and the nitrogen cycle in California chaparral. Science 181:66-68.

Christensen, N.L., and C.H. Muller. 1975. Effects of fire on factors controlling plant growth in Adenostoma chaparral. Eco. Mono. 45:29-55.

Dunn, P.H., L.F. DeBano, and G.E. Eberlein. 1979. Effects on burning on chaparral soils: II. Soil microbes and nitrogen mineralization. Soil Sci. Soc. Amer. J. 45:504-514.

Eno, C.F. 1969. Nitrate production in the field by incubating the soil in polyethylene bags. Proc. Soil Sci. Soc. Amer. 24:277-279.

Grove, T.S., A.M. O'Connell, and N. Malajczuk. 1980. Effects of fire on the growth, nutrient content and rate of nitrogen fixation of the cycad Macrozamia riedlei. Aust. J. Bot. 28:271-281.

Hersman, L.E., and D.A. Klein. 1979. Retorted oil shale effects on soil microbiological characteristics. J. Env. Quality. 8:520-524.

Hobbs, N.T., and R.S. Spowart. 1984. Effects of prescribed fire on nutrition of mountain sheep and mule deer during winter and spring. J. Wildl. Manage. 48:551-560.

Jorgensen, J.R., and C.G. Wells. 1971. Apparent nitrogen fixation in soil influenced by prescribed burning. Soil Sci. Amer. Proc. 35:806-810.

Jurgensen, M.F., A.E. Harvey, and M.L. Larsen. 1981. Effects of prescribed fire on soil nitrogen levels in a cutover Douglas-fir/western larch forest. USDA Forest Serv. Res. Paper No. INT-275.

Kucera, C.L., and J.H. Ehrenreich. 1962. Some effects of annual burning on central Missouri prairie. Ecology 43:334-336.

Lloyd, P.S. 1972. Effects of fire on a Derbyshire grassland community. Ecology 53:915-920.

Manhart, J., and P.P. Wang. 1979. Nitrate effects on nitrogen fixation (acetylene reduction) activities of legume root nodules induced by rhizobia varried nitrate activities. Plant Physiol. 65:502-505.

Marr, J.W. 1967. Ecosystems of the east slope of the Front Range in Colorado. Series in Biology No. 8. Univ. Colorado, Boulder. 
Old, S.M. 1969. Microclimate, fire, and plant production in an Illinois prairie. Ecol. Monogr. 39:355-384.

Oghoghorie, C.G.D., and J.S. Pate. 1971. The nitrate stress syndrome of the nodulated field pea (Pisum arvense L.). p. 185-202. In: T.A. Lie, and E.G. Mulder, eds. Biological nitrogen fixation in natural and agricultural habitats. Plant and soil special volume. Martinus Nijhoft, The Hague.

Peet, M., R. Anderson, and M.S. Adams. 1975. Effect of fire on big bluestem production. Amer. Midl. Natur. 94:15-26.

Raison, R.J. 1979. Modification of the soil environment by vegetation fires with particular reference to nitrogen transformations: A review. Plant and Soil 51:73-108.

Raison, R.J., and J.W. McGarity. 1980. Effects of ash, heat, and the ash-heat interaction on biological activities in two contrasting soils. 1 . Respiration rate. Plant and soil 55:363-376.

Schimel, D.S. 1982. Nutrient and organic matter dynamics in grasslands: Effects of fire and erosion. Ph.D. Diss. Colorado State Univ., Fort Collins.

Scotter, G.W. 1963. Effects of forest fires on soil properties in Northern Saskatchewan. For. Chron. 39:412-421.

Sharrow, S.H., and H.A. Wright. 1977. Effect of fire, ash and litter on soil nitrate, temperature, moisture, and Tobosagrass production in the Rolling Plains. J. Range Manage. 30:266-270.
St. John, T.V., and P.H. Rundel. 1976. The role of fire as a mineralizing agent in a Sierran coniferous forest. Oecologia 25:35-45.

Stanford, G., M.H. Frerre, and D.H. Schwaninger. 1973. Temperature coefficient of soil nitrogen mineralization. Soil Sci. 115:321-323.

Tiwari, V.K., and R. Bharat. 1977. Effect of soil burning on microfungi. Plant and Soil 47:693-697.

Viro, P.J. 1974. Effects of forest fire on soil. P. 7-45. In: T.T. Kozlowski and C.E. Ahlgren, eds. Fire and ecosystems. Academic Press, New York.

Weaver, J.E., and N.W. Rowland. 1952. Effects of excessive natural mulch on development, yield, and structure of native grassland. Bot. Gaz. 114:1-19.

Wells, C.G., R.E. Campbell, L.F. DeBano, C.E. Lewis, R.L. Fredriksen, E.C. Franklin, R.C. Froelich, and P.H. Dunn. 1979. Effects of fire on soil: A state of knowledge review. USDA Gen. Tech. Rep. WO-7.

Wong, P.P. 1980. Nitratc and carbohydrate effects on nodulation and nitrogen fixation activity of lentil. Plant Phys. 66:78-81.

Woodmansee, R.G., and L.S. Wallach. 1981. Effects of fire regimes on biogeochemical cycles. p. 649-669. In: F.E. Clark and T. Rosswall, eds. Terrestrial nitrogen cycles. Ecol. Bull. (Stockholm) 33.

Youngberg, C.T., and A.G. Wollum. 1976. Nitrogen acretion in developing Ceanothus velutinus stands. Soil Sci. Amer. J. 40:109-112.

\section{Call for Associate Editors}

Volunteers are needed to replace associate editors whose terms will expire in February, 1985. The term of office for associate editors is 2 years, with an optional 2 years in addition. Associate editors have the responsibility of directing the review process in designated manuscripts and of making the decision as to acceptance of papers.

Applicants should send the following information to the Editor, Journal of Range Management, 2760 West Fifth Avenue, Denver, CO 80204; (a) Name, address, and telephone number; (b) Areas of expertise; (c) Brief description of experience in reviewing manuscripts (d) Titles of 2 or 3 representative papers that they have published. Applications should reach the Editor by November 30, 1984.

Associate editors play a crucial role in developing and maintaining a high-quality professional journal. The Journal in turn reflects the caliber of the members of the Society and the profession. It is hoped that qualified persons will never be lacking to share the burden and the honor of associate editorship. For additional information, contact, Patricia Smith at the Society headquarters (303) 571-0174. 